\title{
Antifungal Susceptibility Profile In Vitro Fungal Air in a Hospital Environment
}

\author{
Otávio Vilela de Figueiredo1, Luiz Francisley de Paiva², Matheus Valejo Peixoto', \\ Pedro Guilherme Paula Bariani1, Thiago Silva Pinto1, Manoel Araujo Teixeira ${ }^{3}$, \\ Ana Beatriz Alkmim Teixeira-Loyola ${ }^{4}$
}

\author{
${ }^{1}$ School of Medicine, University of the Sapucai Valley, Pouso Alegr, Minas Gerais, Brazil \\ ${ }^{2}$ Research Laboratory, University of the Sapucai Valley, Pouso Alegre, Minas Gerais, Brazil \\ ${ }^{3}$ Department of Biology, University of the Sapucai Valley, Pouso Alegre, Minas Gerais, Brazil \\ ${ }^{4}$ Department of Microbiology, University of the Sapucai Valley, Pouso Alegre, Minas Gerais, Brazil \\ Email:analkmim@hotmail.com
}

How to cite this paper: de Figueiredo, O.V., de Paiva, L.F., Peixoto, M.V., Bariani, P.G.P., Pinto, T.S., Teixeira, M.A. and Teixeira-Loyola, A.B.A. (2018) Antifungal Susceptibility Profile In Vitro Fungal Air in a Hospital Environment. Open Journal of Medical Microbiology, 8, 35-46.

https://doi.org/10.4236/ojmm.2018.83004

Received: March 20, 2018

Accepted: July 1, 2018

Published: July 4, 2018

Copyright $\odot 2018$ by authors and Scientific Research Publishing Inc. This work is licensed under the Creative Commons Attribution International License (CC BY 4.0).

http://creativecommons.org/licenses/by/4.0/

\begin{abstract}
Purpose: The aim of this study was to isolate and identify potentially pathogenic airborne fungi from Hospital das Clínicas Samuel Libânio in the city of Pouso Alegre-MG and evaluate their susceptibility to natural and industrial products. Methods: The air collection was performed by passive sedimentation in the morning during the autumn and winter seasons. Petri dishes were open as the location of air conditioning. The isolates were subjected to pathogenicity test. The identification of the fungi was performed according to the macroscopic evaluation and micromorphology. Potentially pathogenic isolates were susceptibility tested by disc diffusion method. The agents used were insecticides and industrial cleaning products and essential oils of citronella plants, lemon grass, eucalyptus and Melaleuca extracted by steam distillation method. Results: We obtained a total of 356 fungal isolates. The inside door environments were $126(35.39 \%)$ and the outside environments were 230 (64.6\%) isolates. The $22(6.18 \%)$ isolates from the inside and $25(6.18 \%)$ outside the hospital showed pathogenic potential. This isolates were identified as Acremonium spp., A. niger, A. terreus, A. versicolor, Curvularia sp., Penicillium sp. and Scopulariopsis sp. Susceptibility testing it was observed that most of the isolates were susceptible to the principle product containing sodium hypochlorite. Citronella oil showed enormous potential inhibition against all isolates. Already lemon grass oil was effective only against isolates of Penicillium spp. Conclusions: All genres identified are significant allergens, which can cause respiratory disease in both immunocompromised individuals such as asthmatics and people with any immune deficit. The monitoring of environmental sources should be performed, especially in special areas with immunocompromised patients. Despite efforts to try to reduce fungal infections
\end{abstract}


hospital there are still flaws in the strategies employed.

\section{Keywords}

Fungi, Air Conditioning, Housekeeping Hospital, Disk Diffusion Antimicrobial Tests

\section{Introduction}

The Hospital (Nosocomial) Infection (HI) is infections acquired in hospitals or other medical conditions that in the last 25 years has reached more than two million cases per year [1]. In the hospital setting the presence of microorganisms in the air are frequently, floors and walls, and these opportunistically, may preferentially infect the patients who use catheters, dialysis, children, the ancient, immunocompromised, causing severe intra-hospital infections [2]. About $60 \%$ of $\mathrm{HI}$ are connected directly or indirectly to the lack of disinfection and sterilization, thereby facilitating the proliferation of opportunistic microorganisms in immunocompromised patients [1]. In the last years, fungal infections of hospital origin seem to be of great importance, due to its progressive increase and also by high rates of morbidity and mortality [3].

According to data from the Ministry of Health from Brazil, 13\% of patients in hospitals acquire some sort of $\mathrm{HI}$ that greatly impair patients and increase the costs of this type of admission to the Unified Health System [1].

Nosocomial fungal infections have become increasingly frequent, especially in immunocompromised patients from infectious diseases, neoplasms, hemopathies, transplanted and overall postoperative of diverse heart surgeries [4].

The occurrence of infections by airborne fungus is well known in the medical literature and inhaled spores from the air are mainly responsible for many allergic problems and diseases ranging from otitis, mycotoxicosis, urinary tract infections, onychomycosis, eye infections even fungemia. It is a very worry for the clinical medicine, as these microorganisms are dispersed in large scale into the environment [2].

Hospitals have places that require greater attention, when we talk about monitoring critical areas. The most critical areas of hospitals, with a higher probability of $\mathrm{HI}$ transmission are the emergency rooms, surgeries room, the delivery room, and nursery [1] [3]. In pediatric and neonatal intensive care are also considered critical areas because many invasive procedures are performed and also due to the immaturity of the immune system of the newborn and the use of a wide spectrum antibiotic, fungi frequently encountered in the air can become dangerous pathogens [5].

Direct transmission can be through equipment, supplies, hospital procedures and especially by air [1] [3]. Opportunistic fungi of the genus as: Penicillium sp., Aspergillus sp., Cladosporium sp., Candida sp., Fusarium sp. are found in air conditionings [2] [5]. 
In air-conditioned environments, the accumulation of humidity and organic material in the trays of the air conditioning can make them powerful sources of dispersion of bioaerosols. The fungi ability to cause disease in humans appears to be an accidental phenomenon and would be associated with the immune status of the individual and their environmental exposure [4].

It is very important to take measures to control nosocomial infection in ICU, as care regarding sterile technique equipment, control of the presence of visitors and handwashing by employees [5].

The air quality can have a direct and significant influence on the speed recovery of patients and nosocomial infections. Regarding the care of patients with cancer and immunosuppressive diseases, such studies become even more important because these patients are with compromised immune systems [6].

The air conditionings in ICUs provide important information to health professionals on the pathogenicity of fungi isolated, allowing put in place preventive measures and thereby improve the cooled indoor environment, reducing nosocomial hospital infections [7].

Investigations of the occurrence of airborne fungi in hospital settings, opportunistic usually are important for prevention of allergic diseases and hospital infections caused by these pathogens Furthermore, the identification and quantification of their spores may allow advancements in the diagnosis and also the development of new methods of approach in these pathologies [2].

The major wards that were included in the study were heavily contaminated with bacteria and airborne fungi [1]-[11]. There is no report about in vitro antifungal susceptibility of airborne pathogenic fungi to disinfectants, insecticides and essential oil.

Therefore the objective of this study was to monitor the external hospital environment, internal surgical centers and intensive care units isolating airborne fungi potentially pathogenic and evaluate the susceptibility of them in presence of industrial cleaning products and insecticides routinely used and also in the presence of natural essential oils.

\section{Methods}

The study was conducted at the Hospital das Clínicas Samuel Libânio in the city of Pouso Alegre, MG, during the autumn and winter of 2011.

1) Isolation: The samples were collected according to the location of air conditioning, being nine local surgical centers, in three locations of the obstetric surgical room, in three locations in the neonatal ICU and into one general ICU place. The collections were performed by Passive air sampling technique, using open Petri-dishes containing Sabouraud dextrose agar culture media supplemented with chloramphenicol was employed to collect sample once daily. The Petri-dishes were exposed at a distance of 1 meter from the ground, away from the wall, for 15 minutes in the morning for deposition of spores or other structures fungal present in atmospheric air [12] [13]. Incubation was carried out at 
room temperature for 5 - 10 days.

2) Concentration of microorganisms. The airborne concentration of fungi hospital was determined from the difference of the amount of fungi in internal environment in relation to the external environment [14].

3) Temperature Test: For evaluation of potentially pathogenic isolates, these were subjected to growth test temperature of $37^{\circ} \mathrm{C}$ incubated in triplicates for up to seven days inclined tubes Sabouraud agar [15].

4) Fungi's Identification: It was performed only in isolated that grew in $37^{\circ} \mathrm{C}$, as macroscopic analysis according to the genus, based on the morphological characteristics of the colony, as shape and color, and microscopic characteristics of the direct examination of the primary culture [16].

5) Susceptibility test: Considered pathogenic isolates were submitted to susceptibility testing using the agar diffusion method [17]. A physical method in which an organism is challenged against a biologically active substance in solid medium and relates the size of the growth inhibition zone challenged organism [18]. As a positive control to test the cleaning product was used industrialized Slime Daclor Clean ${ }^{\oplus}$, which has in its formula hypochlorite, since chlorine is a effective agent. Other products used were: Veja ${ }^{\circledast} \mathrm{X}-14$ with biodegradable anionic surfactant as the active ingredient, and $\mathrm{Pato}^{\varpi} 5$ in 1, SC JOHNSON, lactic acid with $0.176 \% \mathrm{w} / \mathrm{w}$ as the active ingredient. Both have no chlorine. Other cleaning product was used in fragrances was Sanol ${ }^{\oplus}$ Oil as Citronella, Eucalyptus, Jasmine, Lavender and Pine which its formula is based only on fixing the perfume. Were also tested three insecticides in aerosol forms and three tablets of both SBP Multi ${ }^{\oplus}$ brand insecticide, with the active principle imiprothrin $0.02 \%$, $0.05 \%$ and Permethrin esbiothrin $0.1 \%$ in fragrances Citronella, Eucalyptus and Normal. In addition to these industrial products were tested the susceptibility of fungi compared to essential oils of plants, Cymbopogon winterianus ex Bor Jowitt (citronella) Cymbopogon citratus (DC) Stapf. (Lemon grass), Eucalyptus citriodora (Eucalyptus) and Melaleuca alternifolia (Melaleuca) extracted by steam distillation method [19].

6) Preparation of essential oils: Leaves were collected in the city of Pouso Alegre/MG, in October 2011 for oil extraction. The oil of the fresh leaves was extracted by distillation with water vapor dragging (continuous process) in a modified Clevenger apparatus for 4 horas [19]. After extraction, the material was stored in amber bottle and stored at a temperature at $-4^{\circ} \mathrm{C}$.

7) Antifungal agents: For cleaning products, essential oils and insecticides in aerosol form was applied in $10 \mu \mathrm{L}$ sterile paper discs of Whatman $\mathrm{N}^{\circ} .1$ of $6 \mathrm{~mm}$ in diameter [20]. For tests conducted with insecticide tablets, it was cut into squares in the approximate dimensions of $100 \times 100 \mathrm{~mm}$ in a laminar flow using sterile scissors.

8) The inoculum for the susceptibility test used was $10^{6}$ sporulation on the board.

According to the size of the halo microorganisms were classified as: sensitivity when the diameter of the inhibition halo zone was $>3 \mathrm{~mm}$ being less than the 
positive control; moderately sensitive, halo $>2 \mathrm{~mm}$, less than the positive control of more than $3 \mathrm{~mm}$; and resistant, diameter equal to or less than $2 \mathrm{~mm}$ [21].

\section{Results}

Six collections were made during the fall and 2 collections during the winter. Seventy two and twenty four Petri-dishes were used respectively. A total of 356 fungal filaments isolates were obtained during these seasons from external and internal environment of the hospital (Table 1).

Table 1. Airbone fungi isolated from hospital.

\begin{tabular}{|c|c|c|c|c|c|c|c|c|c|c|c|}
\hline \multicolumn{12}{|c|}{ Collection points } \\
\hline \multirow{2}{*}{$\begin{array}{c}\text { Date of collection } \\
\text { (day/month) }\end{array}$} & & \multicolumn{2}{|c|}{ External environment } & \multicolumn{2}{|r|}{ Neonatal ICU } & \multicolumn{2}{|c|}{ General ICU } & \multicolumn{2}{|c|}{ Surgical center } & \multicolumn{2}{|c|}{ Total } \\
\hline & & $\mathrm{n}$ & $\%$ & $\mathrm{n}$ & $\%$ & $\mathrm{n}$ & $\%$ & $\mathrm{n}$ & $\%$ & $\mathrm{n}$ & $\%$ \\
\hline \multirow[t]{2}{*}{ 24/March } & NI & 18 & 52.9 & 7 & 20.6 & 4 & 11.8 & 5 & 14.7 & 34 & 100 \\
\hline & $\mathrm{T}^{\circ} \mathrm{C}$ & \multicolumn{2}{|r|}{$19^{\circ}-29^{\circ}$} & \multicolumn{2}{|r|}{$25^{\circ}$} & \multicolumn{2}{|c|}{$25^{\circ}$} & \multicolumn{2}{|r|}{$26^{\circ}$} & & \\
\hline \multicolumn{12}{|c|}{ Relative Humidity 12 h UTC: $87 \%$} \\
\hline \multirow[t]{2}{*}{ 08/April } & $\mathrm{NI}$ & 30 & 68.2 & 5 & 11.4 & 3 & 6.8 & 6 & 13.6 & 44 & 100 \\
\hline & $\mathrm{T}^{\circ} \mathrm{C}$ & \multicolumn{2}{|r|}{$14^{\circ}-26^{\circ}$} & \multicolumn{2}{|r|}{$25^{\circ}$} & \multicolumn{2}{|r|}{$25^{\circ}$} & \multicolumn{2}{|r|}{$26^{\circ}$} & & \\
\hline \multicolumn{12}{|c|}{ Relative Humidity 12 h UTC: $81 \%$} \\
\hline \multirow[t]{2}{*}{ 29/April } & NI & 20 & 48.8 & 5 & 12.2 & 7 & 17 & 9 & 22 & 41 & 100 \\
\hline & $\mathrm{T}^{\circ} \mathrm{C}$ & \multicolumn{2}{|r|}{$17^{\circ}-25^{\circ}$} & \multicolumn{2}{|r|}{$25^{\circ}$} & \multicolumn{2}{|c|}{$25^{\circ}$} & \multicolumn{2}{|r|}{$26^{\circ}$} & & \\
\hline \multicolumn{12}{|c|}{ Relative Humidity 12 h UTC: $92 \%$} \\
\hline \multirow[t]{2}{*}{ 12/May } & NI & 17 & 48.6 & 8 & 22.9 & 6 & 17.1 & 4 & 11.4 & 35 & 100 \\
\hline & $\mathrm{T}^{\circ} \mathrm{C}$ & \multicolumn{2}{|r|}{$14^{\circ}-28^{\circ}$} & \multicolumn{2}{|r|}{$25^{\circ}$} & \multicolumn{2}{|c|}{$25^{\circ}$} & \multicolumn{2}{|c|}{$26^{\circ}$} & & \\
\hline & & & & & tive Humidity 1 & JTC: & & & & & \\
\hline 26/May & NI & 30 & 75 & 6 & 15 & 2 & 5 & 2 & 5 & 40 & 100 \\
\hline & $\mathrm{T}^{\circ} \mathrm{C}$ & & $10^{\circ}-23^{\circ}$ & & $25^{\circ}$ & & $25^{\circ}$ & & $26^{\circ}$ & & \\
\hline & & & & & tive Humidity 1 & JTC: & & & & & \\
\hline 10/June & NI & 24 & 75 & 1 & 3.1 & 0 & 0 & 7 & 21.9 & 32 & 100 \\
\hline & $\mathrm{T}^{\circ} \mathrm{C}$ & & $10^{\circ}-16^{\circ}$ & & $25^{\circ}$ & & $25^{\circ}$ & & $26^{\circ}$ & & \\
\hline & & & & & tive Humidity 1 & JTC: & & & & & \\
\hline 29/June & $\mathrm{NI}$ & 52 & 71.2 & 4 & 5.5 & 13 & 17.8 & 4 & 5.5 & 73 & 100 \\
\hline & $\mathrm{T}^{\circ} \mathrm{C}$ & & $15^{\circ}-23^{\circ}$ & & $25^{\circ}$ & & $25^{\circ}$ & & $26^{\circ}$ & & \\
\hline & & & & & tive Humidity 1 & JTC: & & & & & \\
\hline 13/September & NI & 39 & 68.4 & 7 & 12.3 & 6 & 10.5 & 5 & 8.8 & 57 & 100 \\
\hline & $\mathrm{T}^{\circ} \mathrm{C}$ & & $14^{\circ}-30^{\circ}$ & & $25^{\circ}$ & & $25^{\circ}$ & & $26^{\circ}$ & & \\
\hline & & & & & tive Humidity 1 & JTC: & & & & & \\
\hline
\end{tabular}

ICU: Intensive Care Unit. NI: Isolates number; $\mathrm{T}^{\circ} \mathrm{C}$ : Temperature in degrees Celsius. 
During the period of the work, the temperature ranged between $14^{\circ} \mathrm{C}$ and $25^{\circ} \mathrm{C}$ and the relative humidity around $87 \%$. Under these conditions 126 (35.39\%) fungal were isolated from internal environments and 230 (64.6\%) of external environments $(\mathrm{I} / \mathrm{E}=0.55)$. Of these isolates, $47(13.2 \%)$ grew at $37^{\circ} \mathrm{C}$ presenting pathogenic potential. Found $22(6.18 \%)$ within the hospital and 25 (7.02\%) in the environment $(\mathrm{I} / \mathrm{E}=0.88)$ (Figure 1$)$.

The fungi were grown at $37^{\circ} \mathrm{C}: A$. niger (40\%), A. versicolor (20\%) and Penicillium sp (40\%) isolates the surgical centers (I/E $=0.4)$; A. niger $(45.45 \%), A s$ pergillus sp. (45.45\%) and Curvularia sp. (9.09\%) isolates of the ICU (I/E = $0.44) ;$ A versicolor $(100 \%)$ found in the neonatal ICU (I/E = 0.04) and Acremonium sp. (4\%), A. niger (24\%), A. terreus (20\%), A. versicolor (16\%), Curvularia sp. (8\%), Penicillium sp. (24\%) and Scopulariopsis sp. (4\%) filaments isolates the external environment.

The susceptibility of these fungi opposite the cleaners, insecticides and essential oils by the disk diffusion test is shown in Table 2 .

All isolates were susceptible to product containing as its principle active sodium hypochlorite, the exception of $A$. terreus.

The inhibition ranged from 10 to $20 \mathrm{~mm}$ while the $A$. terreus was considered moderately sensitive with halo $4 \mathrm{~mm}$.

In the tests conducted by cleaners without adding chlorine in your formula, all isolates of $A$. niger were moderately sensitive with the brand containing anionic surfactant as the active ingredient while another brand with lactic acid did not offer any resistance.

No scented oil industrial cleaning showed resistance to fungal growth as well as any insecticide tested.

In tests realized with essential oils, oil of citronella (Cymbopogon winterianus Jowitt ex Bor) showed enormous potential of inhibition. The isolates of $A$. niger were the most sensitive with a halo of at least $49 \mathrm{~mm}$ plates and some inhibition was complete (CI) not showing some growth (Figure 2).

A. versicolor and Penicillium sp. were also sensitive to this oil showing two types of halo, an inhibition (h1) and a partial inhibition (h2) where had the growth of fungal hyphae but without sporulation (Figure 3 ).

About the oil's Lemon Grass (Cymbopogon citratus (DC) Stapf) was effective only against isolates of Penicillium sp.

The essential oils of Melaleuca (Melaleuca alternifolia) and Eucalyptus (Eucalyptus citriodora) offered no resistance to the isolates tested.

\section{Discussion}

There is, in Brazil, standards regulating air quality, in particular those established by ANVISA. One of these is Resolution 9 of 16 January 2003 establishing benchmarks for quality of indoor air in artificially air-conditioned environments, as it is for public use or collective [14].

During the fall and winter, the concentration of airborne microorganisms in indoor areas was $\mathrm{I} / \mathrm{E}=0.55$ being within the limit $\mathrm{I} / \mathrm{E} \leq 1.5$ suggested by the 


\section{Potentially Pathogenic Airborne Fungi}

- No growth at $37^{\circ} \mathrm{C}$ = Growth at $37^{\circ} \mathrm{C}$

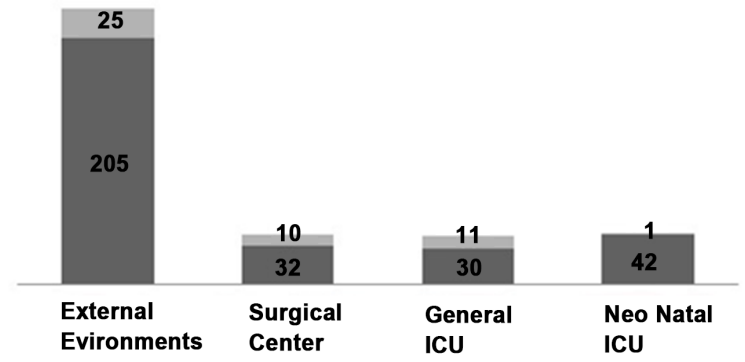

Figure 1. Airborne fungi potential pathogenic isolated in the hospital environment.

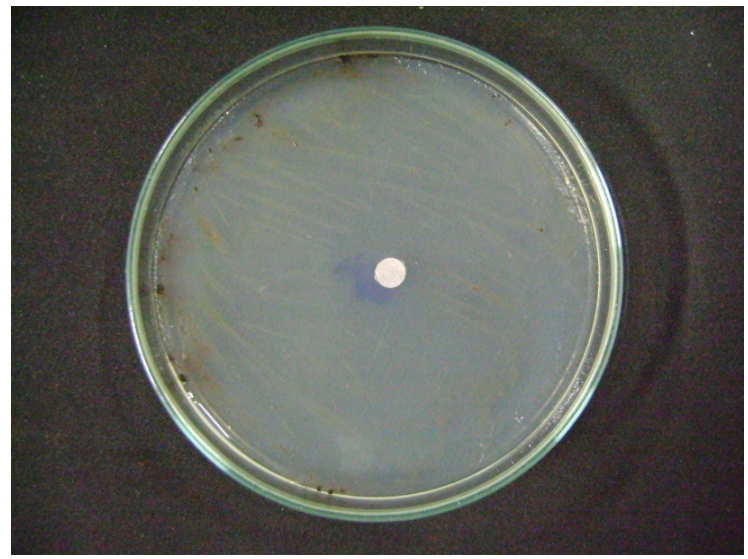

Figure 2. Completely inhibited Aspergillus niger against Citronella essential oils (Cymbopogon winterianus Jowitt ex Bor).

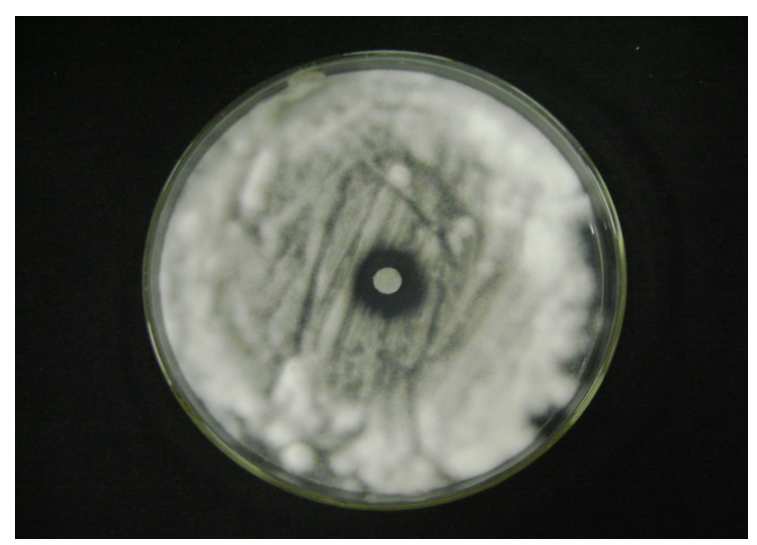

Figure 3. Partial inhibition Penicillium sp. against Lemon grass essential oils (Cymbopogon citratus (D.C.) Stapf).

National Health Surveillance Agency (Agência Nacional de Vigilância Santirária-ANVISA) for microbiological contamination, however, this recommendation is not specific to hospitals [14]. In a work done by Sales et al. [10] (2011) 
Table 2. Susceptibility test of fungi against the cleaners, insecticides and essential oils.

\begin{tabular}{|c|c|c|c|c|c|c|c|c|c|c|c|c|c|}
\hline \multirow{3}{*}{ Location } & \multirow{3}{*}{ Isolated } & \multicolumn{6}{|c|}{ Industrialized product } & \multicolumn{6}{|c|}{ Essential oils } \\
\hline & & $\begin{array}{c}\text { Slime Daclor } \\
\text { Clean }^{\oplus} \text { (Control) }\end{array}$ & \multirow{2}{*}{$\begin{array}{c}\text { Pato }^{\infty} 5 \\
\text { in } 1\end{array}$} & \multirow{2}{*}{$\begin{array}{l}\text { Veja }^{\circ} \\
\text { X-14 }\end{array}$} & \multirow{2}{*}{$\begin{array}{c}\text { Sanol }^{\circledR} \\
\text { Oil }\end{array}$} & \multirow{2}{*}{$\begin{array}{l}\mathrm{SBP}^{\infty} \\
\text { aerosol }\end{array}$} & \multirow{2}{*}{$\begin{array}{l}\mathrm{SBP}^{\infty} \\
\text { tablets }\end{array}$} & \multirow{2}{*}{ Eucalyptus } & \multirow{2}{*}{ Melaleuca } & \multicolumn{2}{|c|}{ Citronella } & \multicolumn{2}{|c|}{$\begin{array}{c}\text { Lemon } \\
\text { grass }\end{array}$} \\
\hline & & h1 & & & & & & & & h1 & h2 & h1 & h2 \\
\hline & A. niger & 14 & $\mathrm{R}$ & MS & $\mathrm{R}$ & $\mathrm{R}$ & $\mathrm{R}$ & $\mathrm{R}$ & $\mathrm{R}$ & & & $\mathrm{R}$ & $\mathrm{R}$ \\
\hline \multirow[t]{3}{*}{ Surgical center } & A. versicolor & 13.5 & $\mathrm{R}$ & $\mathrm{R}$ & $\mathrm{R}$ & $\mathrm{R}$ & $\mathrm{R}$ & $\mathrm{R}$ & $\mathrm{R}$ & 21 & 44 & $\mathrm{R}$ & $\mathrm{R}$ \\
\hline & Penicillium sp. & 17.5 & $\mathrm{R}$ & $\mathrm{R}$ & $\mathrm{R}$ & $\mathrm{R}$ & $\mathrm{R}$ & $\mathrm{R}$ & $\mathrm{R}$ & & & 16 & 53 \\
\hline & Aspergillus sp. & 14 & $\mathrm{R}$ & $\mathrm{R}$ & $\mathrm{R}$ & $\mathrm{R}$ & $\mathrm{R}$ & $\mathrm{R}$ & $\mathrm{R}$ & & & $\mathrm{R}$ & $\mathrm{R}$ \\
\hline \multirow[t]{2}{*}{ General ICU } & A. niger & 17.5 & $\mathrm{R}$ & MS & $\mathrm{R}$ & $\mathrm{R}$ & $\mathrm{R}$ & $\mathrm{R}$ & $\mathrm{R}$ & & & $\mathrm{R}$ & $\mathrm{R}$ \\
\hline & Curvularia sp. & 13 & $\mathrm{R}$ & S & $\mathrm{R}$ & $\mathrm{R}$ & $\mathrm{R}$ & $\mathrm{R}$ & $\mathrm{R}$ & 15 & 0 & $\mathrm{R}$ & $\mathrm{R}$ \\
\hline Neonatal ICU & A. versicolor & 15 & $\mathrm{R}$ & $\mathrm{R}$ & $\mathrm{R}$ & $\mathrm{R}$ & $\mathrm{R}$ & $\mathrm{R}$ & $\mathrm{R}$ & 19 & 40 & $\mathrm{R}$ & $\mathrm{R}$ \\
\hline \multirow{7}{*}{$\begin{array}{c}\text { External } \\
\text { environment }\end{array}$} & Acremonium sp. & 15 & $\mathrm{R}$ & $\mathrm{R}$ & $\mathrm{R}$ & $\mathrm{R}$ & $\mathrm{R}$ & $\mathrm{R}$ & $\mathrm{R}$ & 17 & 0 & $\mathrm{R}$ & $\mathrm{R}$ \\
\hline & A. niger & 14 & $\mathrm{R}$ & MS & $\mathrm{R}$ & $\mathrm{R}$ & $\mathrm{R}$ & $\mathrm{R}$ & $\mathrm{R}$ & 49 & 0 & $\mathrm{R}$ & $\mathrm{R}$ \\
\hline & A. terreus & 4 & $\mathrm{R}$ & $\mathrm{R}$ & $\mathrm{R}$ & $\mathrm{R}$ & $\mathrm{R}$ & $\mathrm{R}$ & $\mathrm{R}$ & & $\Gamma$ & $\mathrm{R}$ & $\mathrm{R}$ \\
\hline & A. versicolor & 15 & $\mathrm{R}$ & $\mathrm{R}$ & $\mathrm{R}$ & $\mathrm{R}$ & $\mathrm{R}$ & $\mathrm{R}$ & $\mathrm{R}$ & 22 & 38 & $\mathrm{R}$ & $\mathrm{R}$ \\
\hline & Curvularia sp. & 14.5 & $\mathrm{R}$ & $\mathrm{R}$ & $\mathrm{R}$ & $\mathrm{R}$ & $\mathrm{R}$ & $\mathrm{R}$ & $\mathrm{R}$ & & $\Gamma$ & $\mathrm{R}$ & $\mathrm{R}$ \\
\hline & Penicillium sp. & 12.5 & $\mathrm{R}$ & $\mathrm{R}$ & $\mathrm{R}$ & $\mathrm{R}$ & $\mathrm{R}$ & $\mathrm{R}$ & $\mathrm{R}$ & 13 & 46 & 13 & 46 \\
\hline & Scopulariopsis sp. & 11.5 & $\mathrm{R}$ & $\mathrm{R}$ & $\mathrm{R}$ & $\mathrm{R}$ & $\mathrm{R}$ & $\mathrm{R}$ & $\mathrm{R}$ & & $\Gamma$ & $\mathrm{R}$ & $\mathrm{R}$ \\
\hline
\end{tabular}

R: Resistance; MS: Moderately sensitive; S: Sensitive; IT: Completely inhibited; h1: inhibition Halo; h2: partial inhibition (growth of fungal hyphae without sporulation).

in the same hospital, the concentration of fungi in indoor environments was $\mathrm{I} / \mathrm{E}$ $=0.2$ in the winter and $\mathrm{I} / \mathrm{E}=0.8$ in the summer.

There was an average of 42 isolates per critical area (operating room, general ICU and Neonatal's ICU) where I/E was equal to 0.18 when compared to the area outside the hospital

The relationship of microorganisms grown at $37^{\circ} \mathrm{C}$ was $\mathrm{I} / \mathrm{E}=0.88$ were classified as pathogenic according Leenders et al. [15]. These results suggest that the external air studied had contamination level greater than the indoor air, in other words, the air that reaches the interior has being filtered while passing through the cooling system.

Several species of airborne fungi is of great importance in medical conditions such as those belonging to the genera Penicillium sp., Aspergillus sp., Mucor sp., Rhizopus sp., Cladosporium sp., Alternaria sp., among others elements that makes it especially allergenic, this factor is very disturbing to clinical medicine, as these microorganisms are thoroughly dispersed in the environment [11].

In this study Aspergillus sp. was the species most commonly found and it had similar results reported by Sales et al. [21]. The fungi of the genus Aspergillus sp. give rise to large amounts of small smooth or rough conidia that easily penetrate the respiratory system and sinuses, causing infections in susceptible patients such as necrotizing pneumonia with risk of hemoptysis, systemic dissemination 
and death [22].

The antimicrobial activity of disinfectants is established by the Ministry of Health through a law determining their tuberculocidal, fungicidal and microbicidal action for $S$. aureus, $P$. aeruginosa and $S$. choleraesuis [23].

Susceptibility testing in front of cleaners, the best result was observed across the Daclor ${ }^{\otimes}$ Clean Limo, which uses sodium hypochlorite, which was expected. This product is routinely used in the hospital. The others products offered no resistance to fungi and is therefore effective in the cleaning process and may be used in association with an Daclor ${ }^{\circledR}$ Clean Limo.

The risk of a nosocomial infection is pretty high if we consider the Brazilian hospitals reality. The beds have high turnover requiring occupy them after their vacancy highlights Andrade et al. [8]. The maintenance and cleaning of the hospital environment is the best way to reduce fungal contaminants. According to Honorato [9], the greater effectiveness of the cleaning process will be the largest security hospital for risk of fungal contamination to patients, however, even when the cleanup is performed correctly fungi dispersed in the air will not be affected, and only the cleaned surfaces have considerably reduced the fungal load, so, control ventilation is required.

The insecticides used in this test had aromas of lemongrass and eucalyptus known to have antimicrobial activity plants, but only the aromatic principle was not sufficient to inhibit fungal growth being negative for all isolates.

The essential oil of citronella proved to be very effective in the susceptibility tests, in some cases, completely inhibited fungal growth on the whole surface of the plate while the oil Sanol ${ }^{\circ}$ and the insecticides tested both with the scent of citronella did not offer any resistance. We can observe that its active antimicrobial principle is not supported only in its perfume, but at some of the many components present in the oil.

The goal is to reduce the maximum microbial threats, so must be used all available resources once hospital infection poses a threat to patients. According to Andrade et al. [8], the choice of product is very important, however should be analyze which are the other factors that are contributing to the irrelevant reduction of microbial load after cleaning.

Several studies have been developed and directed to the discovery of new antimicrobial agents from plant extracts. Nowadays, there is a strong tendency for the use of herbs for many purposes, including its use as antimicrobial agents, considering the composition and the antimicrobial potential of their essential oils, highlights (Salvagnini et al. [24]).

To Ostrosky et al. [25], the research for new antimicrobial agents is necessary due to the emergence of resistant microorganisms and opportunistic infections. Use this study as a first screening in the discovery of the pharmacological activity of new agents should be emphasized. This way, the research can contribute to the development of new products with more effective substances against the resistance of pathogenic microorganisms. 
The limitation of this study was the identified morphological characteristic of filamentous fungi. However, morphological features must be considered together with molecular analysis, as certain characters are indistinguishable between species. The Passive air sampling technique to isolate the fungi of the environment, using open Petri-dishes is not ideal for determining the amount of spores in the environment. The quantitative automatic system could be better to determine the airborne fungi in hospital environment.

\section{Conclusions}

Potentially pathogenic isolates were present both in the fall and winter in external and internal environment. Therefore, attention must be needed to the air conditionings, avoiding the possible entry in the environment of the reproductive spores of pathogenic fungi.

The monitoring of environmental sources should be performed, especially in special areas with immunocompromised patients subjected to exposure to environmental pathogens. Thus, it is possible to design appropriate measures to control these pathogens, as well as the most appropriate therapy instituted.

The maintenance and cleaning of equipment and the entire hospital is still the best way to reduce fungal contaminants and routine using products with sodium hypochlorite is fundamental and indispensable. In this study, processed products with fragrance of plants known to be antimicrobial do not guarantee the elimination of the fungal environment; however, the essential oils are promising.

\section{References}

[1] Fortuna, J.L. and Santana, W.O. (2012) Microbiota de aparelhos de ar condicionado das áreas críticas de hospitais públicos e particulares e sua relação com as infecções hospitalares. Revista Brasileira de Biociências, 18, 56-64.

[2] Carmo, E.S., Belém, L.F., Catão, R.M.R., Lima, E.O., Silveira, I.L. and Soares, L.H.M. (2007) Microbiota fúngica presente em diversos setores de um hospital público em Campina Grande-PB. Revista brasileira de análises clínicas, 39, 213-216.

[3] Martins-Diniz, J.N., Silva, R.A.M., Miranda, E.T. and Mendes-Giannini, M.J.S. (2005) Monitoramento de fungos anemófilos e de leveduras em unidade hospitalar. Revista de Saúde Pública, 39, 398-405. https://doi.org/10.1590/S0034-89102005000300010

[4] Flores, LH. and Onofre, S.B. (2010) Determinação da presença de fungos anemófilos e leveduras em unidade de saúde da cidade de Francisco Beltrão-PR. SaBios-Revista de Saúde e Biologia, 5, 22-26.

[5] Melo, L.L.S., Lima, A.M.C., Damasceno, C.A.V. and Vieira, A.L.P. (2009) Flora fúngica no ambiente da Unidade de Terapia Intensiva Pediátrica e Neonatal em hospital terciário. Revista Paulista de Pediatria, 27, 303-308. https://doi.org/10.1590/S0103-05822009000300011

[6] Quadros, M.E., Lisboa, H.M., Oliveira, V.L. and Schirmer, W.N. (2009) Qualidade do ar em ambientes internos hospitalares: Estudo de caso e análise crítica dos padrões atuais. Revista Engenharia Sanitária, 14, 431-438. https://doi.org/10.1590/S1413-41522009000300017

[7] Mobin, M. and Salmito, M.A. (2006) Microbiota fúngica dos condicionadores de ar 
nas unidades de terapia intensiva de Teresina, PI. Revista da Sociedade Brasileira de Medicina Tropical, 39, 556-559. https://doi.org/10.1590/S0037-86822006000600009

[8] Andrade, D., Angerami, E.L.S. and Padovani, C.R. (2000) Condições microbiológicas dos leitos hospitalares antes e depois de sua limpeza. Revista de Saúde Pública, 34, 163-169. https://doi.org/10.1590/S0034-89102000000200010

[9] Honorato, G.M. (2009) Verificação de fungos anemófilos na U.T.I. do Hospital Santa Lucinda (Sorocaba/SP), antes e depois de sua limpeza. Revista Eletrônica de Biologia, 2, 19-31.

[10] Sales, E., Sales, E.M.L., Dias, L.F., Costa, F.E.C. and Loyola, A.B.A.T. (2011) Micota no ar da unidade de terapia intensiva e centro cirúrgico de um hospital universitário. Bioikos, 25, 109-115.

[11] Souza, A.E.F., Souza, E.F., Costa, H.A., Barbosa, Y.W.F., Júnior, U.P.S. and Vieira, K.V.M. (2010) Microbiota fúngica anemófila de hospitais da rede pública da cidade de Campina Grande PB. Revista de Biologia eFarmacia, 4, 102-116.

[12] Kern, M.E. and Blevins, K.S. (1999) Micologia médica: Texto e atlas. Premier, São Paulo.

[13] Lacaz, C.S., Porto, E., Heins-Vaccari, E.M. and Melo, N.T. (1998) Guia para identificação: Fungos, actinomicetos e algas de interesse médico. Sarvier, São Paulo.

[14] Brasil (2003) Ministério da Saúde. Agência Nacional de Vigilância Sanitária. Resolução $n^{\circ} 9$.

[15] Leenders, A.C.A.P., Van Belkum, A., Behrendt, M., Luijendijk, A. and Verbruch, H.A. (1999) Densit and Molecular Epidemiology of Aspergillus in Air and Relationship to Outebreaks of Aspergillus Infection. Journal of Clinical Microbiology, 37, 1752-1757.

[16] Zaitz, C., Campbell, I., Marques, A.S., Ruiz, L.R.B. and Souza, V.M. (1998) Compêndio de Micologia Médica. Medsi, Rio de Janeiro, 205-218.

[17] Barry, A.L. and Thornsberry, C. (1991) Susceptibility Tests: Diffusion Test Procedures. In: Balows, A., Hauser, W.J., Hermann, K.L., Isenberg, H.D. and Shamody, H.J., Eds., Manual of Clinical Microbiology, American Society for Microbiology, Washington DC, 1117-1125.

[18] Pinto, T.J.A., Kaneko, T.M. and Ohara, M.T. (2003) Controle Biológico de Qualidade de Produtos Farmacêuticos, Correlatos e Cosméticos. Atheneu, São Paulo, 325 p.

[19] (1988) Farmacopéia brasileira. 4a edição, Atheneu, São Paulo, Capítulo V.4.2.6.

[20] Rabanal, R.M., Arias, A., Prado, B., Hernández-Perez, M. and Sánchez-Mateo, C.C. (2002) Antimicrobial Studies on Three Species of Hypericum from the Canary Islands. Journal Ethnopharmacology, 81, 287-292. https://doi.org/10.1016/S0378-8741(02)00083-1

[21] Springfield, E.P., Amabeoku, G., Weitz, F., Mabusela, W. and Johnson, Q. (2003) An Assessment of Two Carpobrotus Species Extracts as Potential Antimicrobial Agents. Phytomedicine, 10, 434-439. https://doi.org/10.1078/0944-7113-00263

[22] Meersseman, W., Lagrou, K., Maertens, J. and Van Wijngaerden, E. (2007) Invasive Aspergillosis in the Intensive Care Unit. Clinical Infectious Diseases, 45, 205-216. https://doi.org/10.1086/518852

[23] Ministério da Saúde (1998) Portaria n. 2616. Dispõe sobre: Programa de Controle de infecção Hospitalar. Diário Oficial, Brasília de 12 de maio de 1998.

[24] Salvagnini, L.E., Oliveira, J.R.S., Santos, L.E., Moreira, R.R.D. and Pietro, R.C.L.R. (2008) Avaliação da atividade antibacteriana de folhas de Myrtus communis L. 
(Myrtaceae). Revista Brasileira de Farmácia, 18, 241-244.

https://doi.org/10.1590/S0102-695X2008000200018

[25] Ostrosky, E.A., Mizumoto, M.K., Lima, M.E.L., Kaneko, T.M., Nishikawa, S.O. and Freitas, B.R. (2008) Métodos para avaliação da atividade antimicrobiana e determinação da concentração mínima inibitória (CMI) de plantas medicinais. Revista Brasileira de Farmácia, 18, 301-307.

https://doi.org/10.1590/S0102-695X2008000200026 